\title{
Partition coefficients of some industrial aliphatic hydrocarbons (C5-C7) in blood and human tissues
}

\author{
L PERBELLINI, F BRUGNONE, D CARETTA, AND G MARANELLI \\ From the Institute of Occupational Medicine, University of Verona, Verona, Italy
}

ABSTRACT Saline/air, blood/air, olive oil/air, and tissue/air (lung, kidney, liver, brain, muscle, heart, and fat) partition coefficients were determined for nine aliphatic hydrocarbons: n-pentane, 2,2-dimethylbutane, 3-methylpentane, 2-methylpentane, methylcyclopentane, n-hexane, cyclohexane, 3-methylhexane, and n-heptane. Blood/air partition coefficients were found to range between 0.38 (n-pentane) and 1.9 (n-heptane) and the value of the tissue/air partition coefficients rose from n-pentane to $n$-heptane. The tissue/air partition coefficients were significantly correlated with the blood/air partition coefficients $(r=0 \cdot 92-0.98)$. According to the slope of the regression lines, the mean solubility of the nine aliphatic hydrocarbons in the different tissues was higher than in blood by the factors: lung 1.4 (range $1 \cdot 2-2 \cdot 1$ ), heart 3.9 (range $0 \cdot 5-4 \cdot 5$ ), liver $5 \cdot 6$ (range $5 \cdot 5-13 \cdot 5$ ), kidney $5 \cdot 2$ (range $1 \cdot 6-5 \cdot 8$ ), brain $6 \cdot 5$ (range $5 \cdot 8$ $10 \cdot 7$ ), muscle 7.6 (range 1.8-8.8), and fat 205 (range 104-254). The blood/air and olive oil/air partition coefficients were significantly correlated with the boiling points and the molecular weights of the aliphatic hydrocarbons studied.

The uptake and distribution of industrial solvents are important in the understanding of their pharmacokinetics, body burden, and physiopathological effects. A knowledge of the blood/air and tissue/ blood partition coefficients of these solvents will give some insight into the rate of pulmonary exchange and tissue kinetics. For a few products (cycloproprane, chloroform, diethyl ether, ethyl chloride, trichloroethylene) which in the past were used as anaesthetics, the solubility in blood and in the most important tissues have been reported. ${ }^{12}$ On the other hand, for most compounds used as solvents in industry and in the home, although the solubility in water and in other solvents can be found in reports the solubility in blood or body tissues cannot, although the solubility of a few aromatic hydrocarbons, ketones, alcohols, and halogenated hydrocarbons in the blood and in olive oil has recently been studied. ${ }^{3-7}$

We report on the findings of a study of the solubility of nine aliphatic hydrocarbons in blood, saline, olive oil, and in the most important human tissueslung, liver, kidney, fat, brain, heart, and muscle. We

Received 23 February 1984

Accepted 2 April 1984 also discuss relations between the partition coefficient of these solvents and their physical properties.

\section{Materials and methods}

The following solvents were used: n-pentane, 2,2dimethylbutane, 2-methylpentane, 3-methylpentane, n-hexane, cyclohexane, methylcyclopentane, 3-methylhexane, and n-heptane. All were obtained from C Erba (Milan) and were more than $98 \%$ pure.

Human tissues (lung, kidney, heart, brain, liver, muscle, and fat) were collected from two men who had died suddenly from a heart attack when aged 30 and 40 respectively. No histological abnormalities were found in the tissues used. The individual tissues were homogenised in saline and frozen at $-75^{\circ} \mathrm{C}$ until the experiments. Stored human blood was obtained from a hospital blood bank.

The solubility of the solvents in saline, blood, olive oil, and homogenated tissues was determined according to the method described by Sato and Nakajima $^{4}$ with minor modifications. Five samples of $2 \mathrm{ml}$ of each homogenised tissue were put in to test tubes of $11.6 \mathrm{ml}$ capacity. We added $10-20 \mu \mathrm{g}$ of each solvent (corresponding to $20-40 \mu \mathrm{g} / \mathrm{ml}$ of tissue) to the test tubes containing $2 \mathrm{ml}$ of homogen- 
ised tissue. For each test tube containing solvents and tissue, a test tube containing solvents only was also prepared. The test tubes were sealed with a screw cap lined with rubber and Teflon and were kept for 12 hours in a rotating agitator in a room at $37^{\circ} \mathrm{C}$. The concentrations of solvents were then measured in the head space of the test tubes, both with and without the homogenised tissues. In order to test the solubility in saline, blood, or olive oil these liquids were used in place of the solid tissues. For the solubility in saline $70 \mathrm{ml}$ of the solution was used in flasks of $75 \mathrm{ml}$ capacity. The solvents were put in two flasks, one containing the saline and the other empty. To determine the solubility of the solvents in olive oil and blood, $0.5 \mathrm{ml}$ and $2 \mathrm{ml}$ respectively were used. The gas chromatographic determinations of the solvent concentrations in the head space were carried out with a Perkin Elmer GC mod F 17 or a C Erba GC mod 4160 as previously described $^{8} 9$ connected with a Spectra-Physics integrator mod SP 4270. To validate the method we made some preliminary measurements of the solubility of trichloroethylene in saline, blood, olive oil, and the available tissues. The results we obtained were similar to those already reported. ${ }^{2}$

The blood/air and olive oil/air partition coefficients reported here are the arithmetical mean of 10 samples, whereas the tissue/air partition coefficients are the mean of five samples. The best fit of the linear and exponential regression lines was calculated by the method of least squares.

\section{Results}

The table shows the solubility of the aliphatic hydrocarbons in blood, olive oil, and tissues. The solubility in saline was low, with a partition coefficient in the range $0 \cdot 1$ to 0.4 for all nine compounds studied. The solubility was greatest in olive oil partition coefficients ranging from 47 (pentane) to 452 (nheptane). As may be seen from the table, the blood/air partition coefficient is 0.38 for pentane and rises to 0.8 for $n$-hexane, to 1.3 for cyclohexane, and to 1.9 for $n$-heptane. In the tissues the solubility of the individual hydrocarbons follows a similar trend to that in the blood, being lowest in pentane to n-hexane, cyclohexane, and greatest in n-heptane (table, fig 1). The solubility of the solvents shows a gradual gradient from blood to liver, but increases steeply from liver to fatty tissues (fig 1).

In figs 2-8 the solubility in blood (blood/air partition coefficient) has been compared with the solubility in the tissues (tissues/air partition coefficient) and it may be seen that the two are significantly correlated for all nine hydrocarbons considered together ( $r$ between 0.92 and 0.98 ). From the slope of the graphs it can be determined that the mean solubility of these solvents in the heart, lung, liver, kidney, brain, muscle, and fat is 3.9 (range $0.5-4.5$ ), 1.4 (range 1.2-2), 5.6 (range 5.5-13.5), 5.2 (range $1 \cdot 6-5 \cdot 8$ ), $6 \cdot 5$ (range $5 \cdot 8-10 \cdot 7$ ), $7 \cdot 6$ (range $1 \cdot 8-8 \cdot 8$ ), and 205 (range 104-253) times that in the blood respectively.

The solubility of the hydrocarbons in fat was 104-253 times that in the blood and was similar to the solubility in olive oil (123-273 times the solubility in blood). The olive oil/air partition coefficients (y) and the blood/air partition coefficients $(x)$ were significantly correlated $(y=244 \times-12 ; r=0.99$; $\mathrm{n}=9 ; \mathrm{p}<0.001$ ).

The solubility of the solvents in blood, olive oil, and in the other tissues increased exponentially according to the increase in the boiling point of the individual hydrocarbons. The exponential correla-

Olive oil/air, blood/air, and tissues/air partition coefficients of the C5-C7 aliphatic hydrocarbons. (Standard deviation in parentheses)

\begin{tabular}{|c|c|c|c|c|c|c|c|c|c|}
\hline Solvents & Oil & Blood & Liver & Kidney & Brain & Fat & Muscle & Heart & Lung \\
\hline n-Pentane & $\begin{array}{c}47 \\
(2 \cdot 3)\end{array}$ & $\begin{array}{c}0.38 \\
(0.08)\end{array}$ & $\begin{array}{r}2 \cdot 1 \\
(0 \cdot 9)\end{array}$ & $\begin{array}{c}0 \cdot 6 \\
(0.3)\end{array}$ & $\begin{array}{r}2 \cdot 2 \\
(0.5)\end{array}$ & $\begin{array}{l}39.6 \\
(2.6)\end{array}$ & $\begin{array}{r}0.7 \\
(0.4)\end{array}$ & $\begin{array}{c}0 \cdot 2 \\
(0.4)\end{array}$ & $\begin{array}{l}0.5 \\
(0.03)\end{array}$ \\
\hline 2,2-Dimethylbutane & $\begin{array}{c}71 \\
(5 \cdot 5)\end{array}$ & $\begin{array}{c}0.26 \\
(0.08)\end{array}$ & $\begin{array}{r}3.5 \\
(1.1)\end{array}$ & $\begin{array}{l}1.4 \\
(1 \cdot 1)\end{array}$ & $\begin{array}{r}2.8 \\
(0.3)\end{array}$ & $\begin{array}{c}66 \\
(4.0)\end{array}$ & $\begin{array}{r}1.0 \\
(0.8)\end{array}$ & $\begin{array}{c}0.5 \\
(0.4)\end{array}$ & $\begin{array}{c}0.6 \\
(0.06)\end{array}$ \\
\hline 2-Methylpentane & $\begin{array}{l}103 \\
(7 \cdot 3)\end{array}$ & $\begin{array}{c}0.41 \\
(0.07)\end{array}$ & $\begin{array}{r}4 \cdot 5 \\
(1 \cdot 1)\end{array}$ & $\begin{array}{c}2.0 \\
(1 \cdot 1)\end{array}$ & $\begin{array}{r}3.8 \\
(0.3)\end{array}$ & $\begin{array}{c}87^{\prime} \\
(7.0)\end{array}$ & $\begin{array}{r}2.9 \\
(0.9)\end{array}$ & $\begin{array}{c}1.4 \\
(0.8)\end{array}$ & $\begin{array}{c}0.8 \\
(0.06)\end{array}$ \\
\hline 3-Methylpentane & 118 & $\begin{array}{c}0.43 \\
0.07\end{array}$ & $\begin{array}{r}4.9 \\
(1.0)\end{array}$ & $\begin{array}{c}2.5 \\
(1.0)\end{array}$ & $\begin{array}{r}4.4 \\
(0.4)\end{array}$ & $\begin{array}{l}102 \\
(8.0)\end{array}$ & $\begin{array}{r}3.8 \\
(0.8)\end{array}$ & $\begin{array}{c}1.9 \\
(0.8)\end{array}$ & $\begin{array}{c}0.9 \\
(0.06)\end{array}$ \\
\hline n-Hexane & $\begin{array}{l}146 \\
(6.9)\end{array}$ & $\begin{array}{c}0.80 \\
(0.08)\end{array}$ & $\begin{array}{r}5.2 \\
(0.7)\end{array}$ & $\begin{array}{c}3 \cdot 0 \\
(1 \cdot 1)\end{array}$ & $\begin{array}{r}5.0 \\
(0.4)\end{array}$ & $\begin{array}{l}104 \\
(10.0)\end{array}$ & $\begin{array}{r}5.0 \\
(0.9)\end{array}$ & $\begin{array}{c}2.8 \\
(0.9)\end{array}$ & $\begin{array}{l}1.0 \\
(0.07)\end{array}$ \\
\hline Methylcyclopentane & 202 & $\begin{array}{c}0.86 \\
(0.08)\end{array}$ & $\begin{array}{r}7.8 \\
(1.0)\end{array}$ & $\begin{array}{c}4 \cdot 7 \\
(1 \cdot 1)\end{array}$ & $\begin{array}{r}7.3 \\
(0.8)\end{array}$ & $\begin{array}{l}176 \\
(10.0)\end{array}$ & $\begin{array}{r}5.0 \\
(0.8)\end{array}$ & $\begin{array}{c}1.9 \\
(0.8)\end{array}$ & $\begin{array}{l}1.7 \\
(0.04)\end{array}$ \\
\hline Cyclohexane & $\begin{array}{l}293 \\
(11.0)\end{array}$ & $\begin{array}{c}1 \cdot 3 \\
(0.1)\end{array}$ & $\begin{array}{c}10.8 \\
(0.9)\end{array}$ & $\begin{array}{c}7.2 \\
(1.0)\end{array}$ & $\begin{array}{c}10.7 \\
(1.4)\end{array}$ & $\begin{array}{l}260 \\
(11 \cdot 0)\end{array}$ & $\begin{array}{c}10.5 \\
(0.7)\end{array}$ & $\begin{array}{c}5.8 \\
(1.0)\end{array}$ & $\begin{array}{l}2.7 \\
(0.1)\end{array}$ \\
\hline 3-Methylhexane & $\begin{array}{l}311 \\
(24 \cdot 0)\end{array}$ & $\begin{array}{c}1 \cdot 3 \\
(0-1)\end{array}$ & $\begin{array}{l}10.6 \\
(1 \cdot 1)\end{array}$ & $\begin{array}{c}7 \cdot 3 \\
(2 \cdot 1)\end{array}$ & $\begin{array}{l}10.2 \\
(1.6)\end{array}$ & $\begin{array}{l}277 \\
(24 \cdot 0)\end{array}$ & $\begin{array}{l}10.8 \\
(0.7)\end{array}$ & $\begin{array}{c}5 \cdot 3 \\
(1 \cdot 2)\end{array}$ & - \\
\hline n-Heptane & $\begin{array}{l}452 \\
(20.0)\end{array}$ & $\begin{array}{l}1.9 \\
(0.1)\end{array}$ & $\begin{array}{l}10.8 \\
(1.0)\end{array}$ & $\begin{array}{c}8.9 \\
(1.2)\end{array}$ & $\begin{array}{r}12 \cdot 4 \\
(2 \cdot 1)\end{array}$ & $\begin{array}{l}385 \\
(13.0)\end{array}$ & $\begin{array}{r}12.5 \\
(0.6)\end{array}$ & $\begin{array}{c}6.1 \\
(1.4)\end{array}$ & $\begin{array}{c}2 \cdot 5 \\
(0.2)\end{array}$ \\
\hline
\end{tabular}




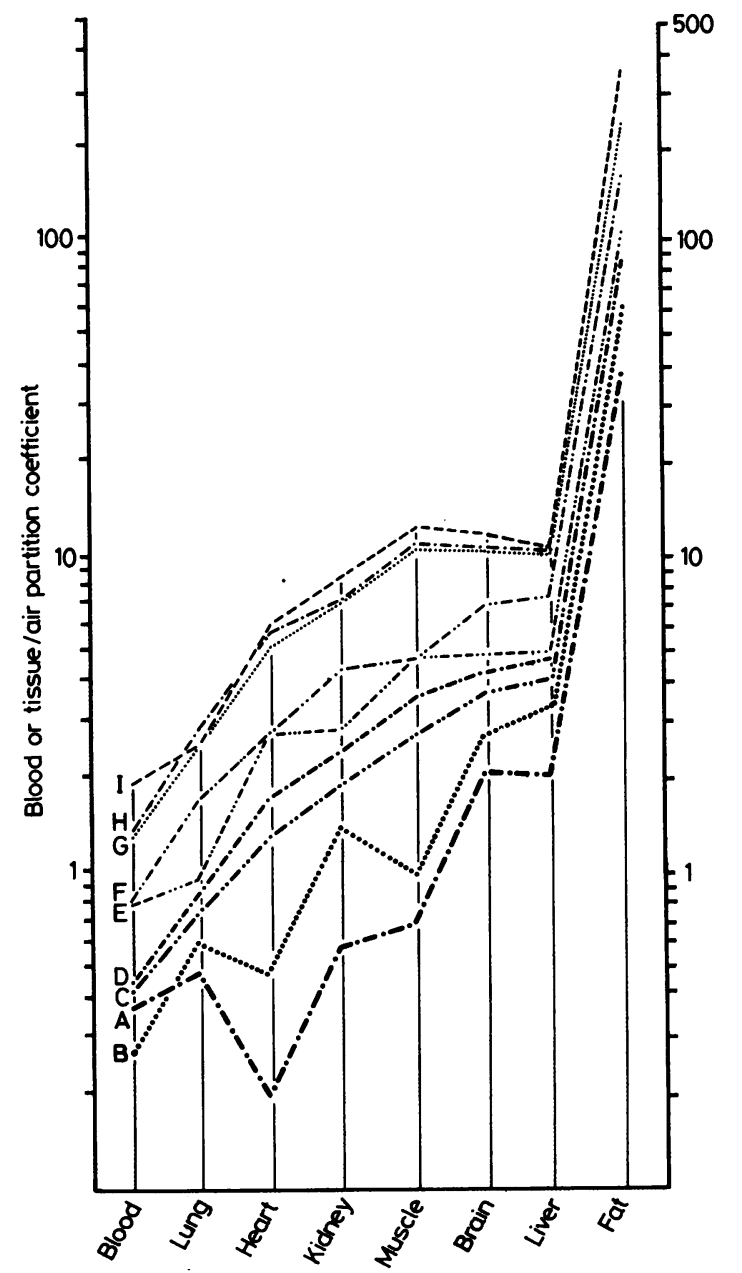

Fig 1 Blood and tissuelair partition coefficients of aliphatic hydrocarbons $(C 5-C 7),(A=$ pentane,

$B=2,2$-dimethylbutane, $C=2$-methylpentane,

$D=3$-methylpentane, $E=n$-hexane,

$F=$ Methylcyclopentane, $G=$ cyclohexane,

$H=3$-methylhexane, $I=n$-heptane).

tion of the solubility of each solvent in the olive oil and blood and its boiling points is shown in fig $9(\mathrm{r}=$ 0.97 and 0.93 ). The solubility of the solvents in blood, olive oil, and in the tissues was also correlated with their molecular weights, but in a linear fashion (fig 10).

Significant correlations between the partition coefficients of the solvents and their melting points and their densities was not found.

\section{Discussion}

For many biologically active compounds, the parti-

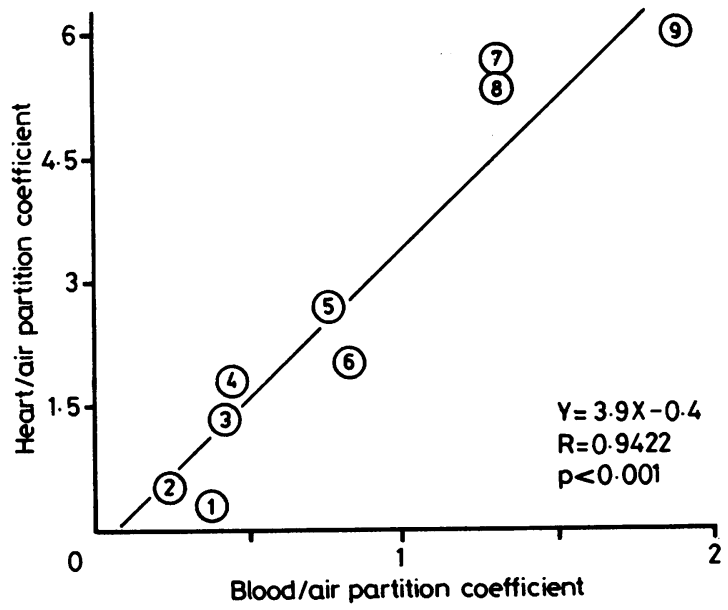

Fig 2 Correlation between heart/air and blood/air partition coefficients of $C 5-C 7$ aliphatic hydrocarbons

(1 = n-pentane, 2 = 2,2-dimethylpentane,

$3=2$-methylpentane, $4=3$-methylpentane, $5=n$-hexane,

$6=$ methylcyclopentane, $7=$ cyclohexane,

$8=3$-methylhexane, $9=n$-heptane).

tion coefficients between blood and air and between tissues and blood are important since the former regulates the uptake of blood and the latter the tissue distribution in the body. The blood solubility of the hydrocarbons which are studied was low, ranging between 0.38 (pentane) and 1.9 (n-heptane), indicating that their respiratory absorption is also low. The alveolar retention of $n$-hexane and its isomers has been found experimentally, in workers, to be between $15 \%$ and $20 \%$ and that of cyclohexane and its isomer, $20.9 \%$ and $15.4 \%$ respectively. ${ }^{.10}$

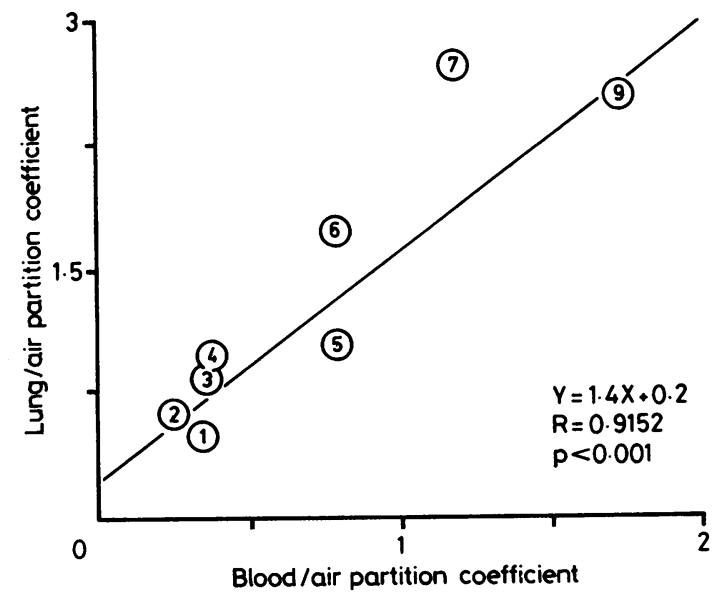

Fig 3 Correlation between lung/air and blood/air partition coefficients of C5-C7 aliphatic hydrocarbons. 


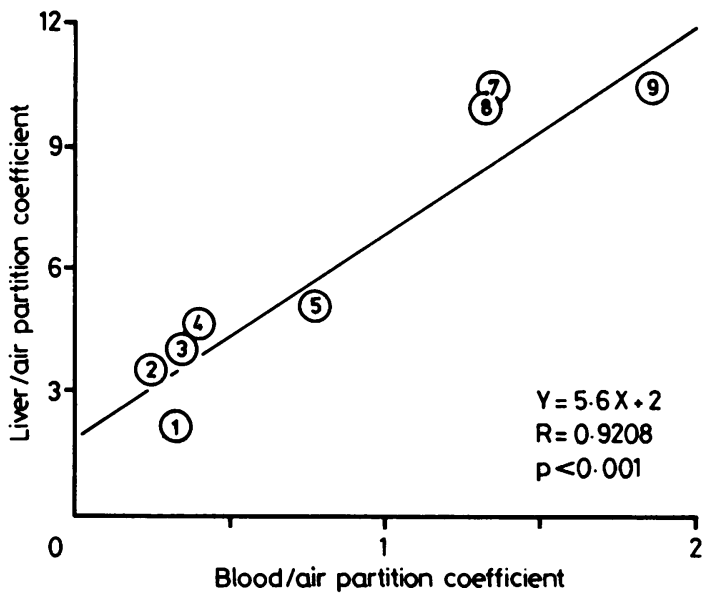

Fig 4 Correlation between liver/air and blood/air partition coefficients of C5-C7 aliphatic hydrocarbons.

The tissue solubility of the hydrocarbons was always higher than in blood, for any tissues studied. With the exception of fat solubility which was 104-253 times that of blood, the solubility in other tissues was, on average, between 1.4 and 7.6 times the blood solubility.

The lowest tissue/blood partition coefficient was found for lung tissue $(1.4$ range $1 \cdot 2-2 \cdot 3)$ and the highest was for muscle $(7 \cdot 6$, range $1 \cdot 8-8 \cdot 7)$. Eger reported that the tissue solubility of inhaled anaesthetics ranged between one and four times the solubility in blood, except for fat solubility. ${ }^{1}$

It is interesting to note that kidney/blood, muscle/blood, liver/blood, and brain/blood partition

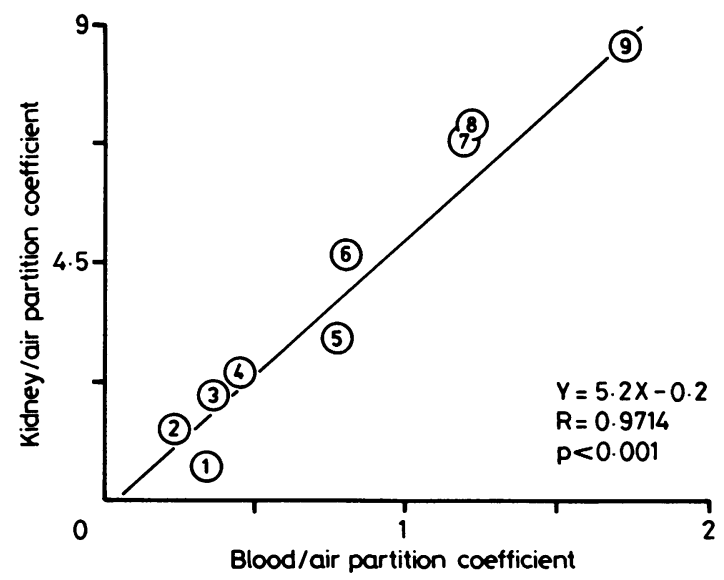

Fig 5 Correlation between kidney/air and blood/air partition coefficients of C5-C7 aliphatic hydrocarbons.

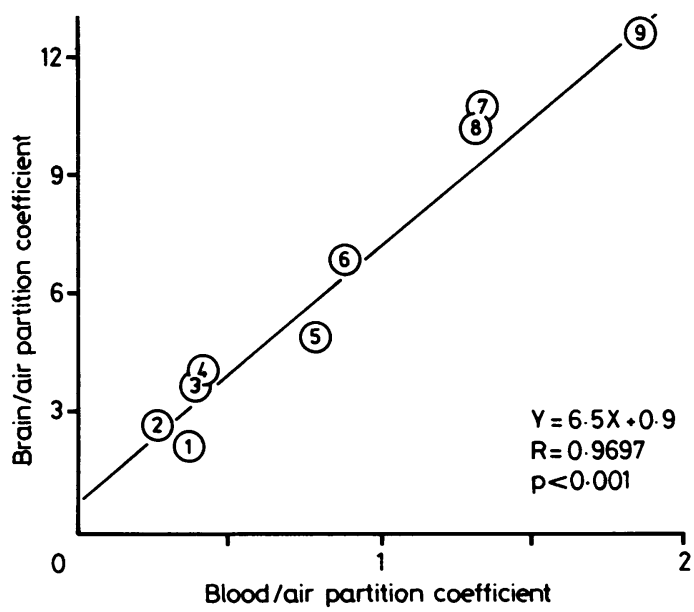

Fig 6 Correlation between brain/air and blood/air partition coefficients of C5-C7 aliphatic hydrocarbons.

coefficients (figs 4-7) were similar for all the hydrocarbons considered individually. These findings refute the common belief that industrial solvents cause neurotoxic effects because the nervous system contains a high amount of lipids which they can easily dissolve and accumulate. Our data show that whatever the content of lipids in the nervous system (lipoproteins and sphingomyelins mainly), the solubility of aliphatic hydrocarbons in brain tissue is no higher than that in muscle, liver, or kidney tissue. This result is in accordance with other data which show that the solubility of trichloroethylene and

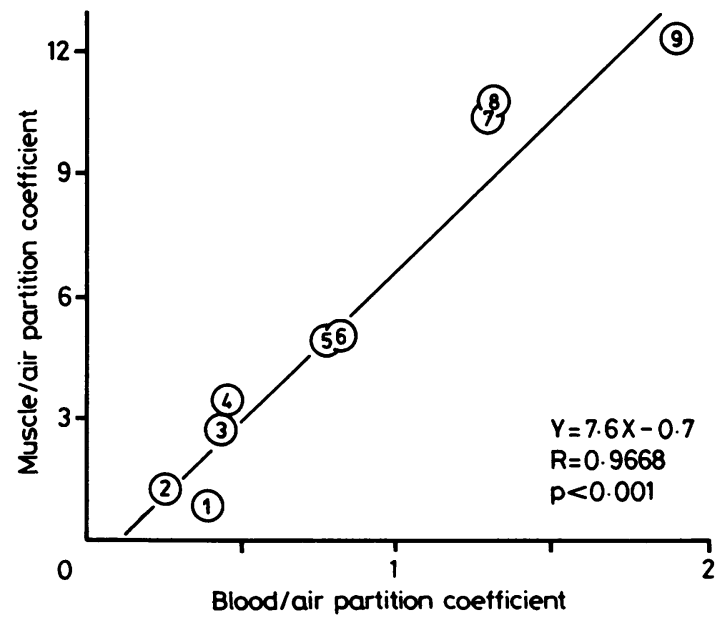

Fig 7 Correlation between muscle/air and blood/air partition coefficients of C5-C7 aliphatic hydrocarbons. 


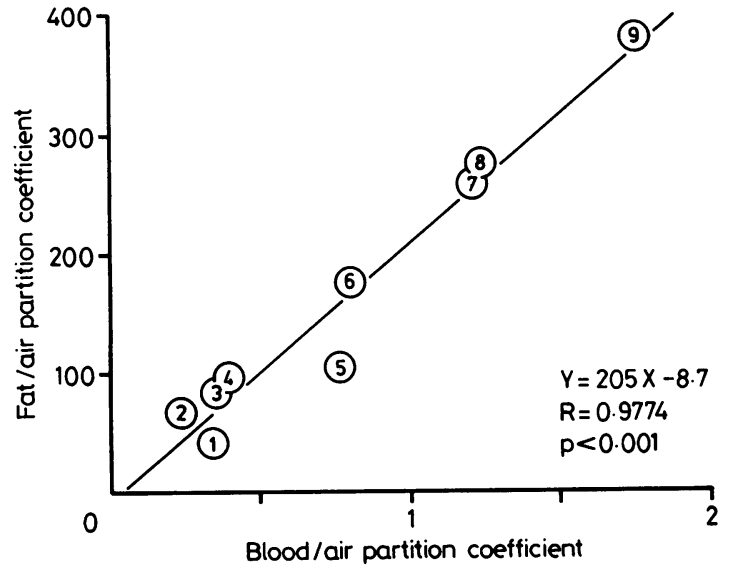

Fig 8 Correlation between fat/air and blood/air partition coefficients of C5-C7 aliphatic hydrocarbons.

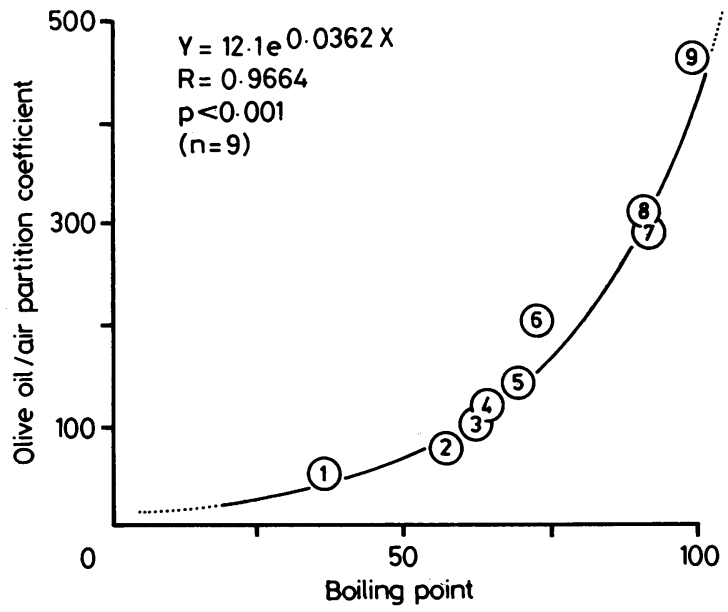

other anaesthetics in the brain is similar to that in the other tissues. ${ }^{2}$ Our study has also shown that the solubility of some hydrocarbons in blood and in olive oil was directly correlated with their boiling points according to an exponential curve (fig 9). A linear correlation was found between solubility and molecular weight (fig 10).

We have also examined data on the solubility of aromatic hydrocarbons, ketones, and chlorinated hydrocarbons in water, blood, and olive oil reported by Sato and Nakajima. ${ }^{45}$ By contrast with these authors, we found a good correlation between the solubility of hydrocarbons in olive oil and their boiling points. Figure 11 shows the exponential correlation between the boiling points and the solubility in olive oil for the hydrocarbons studied by us and for those studied by Sato and Nakajima. ${ }^{45}$ With the exception of the ketones an exponential correlation

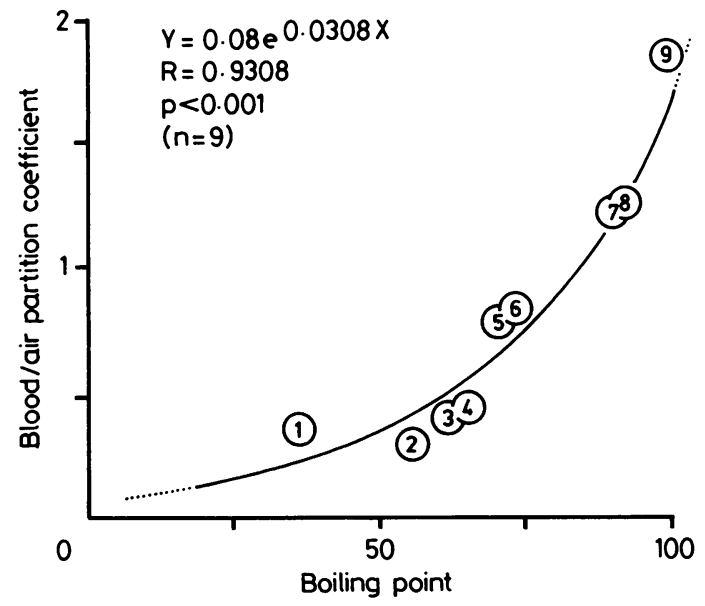

Fig 9 Correlation between olivelair and blood/air partition coefficients and boiling point of $\mathrm{C5}-\mathrm{C} 7$ aliphatic hydrocarbons.
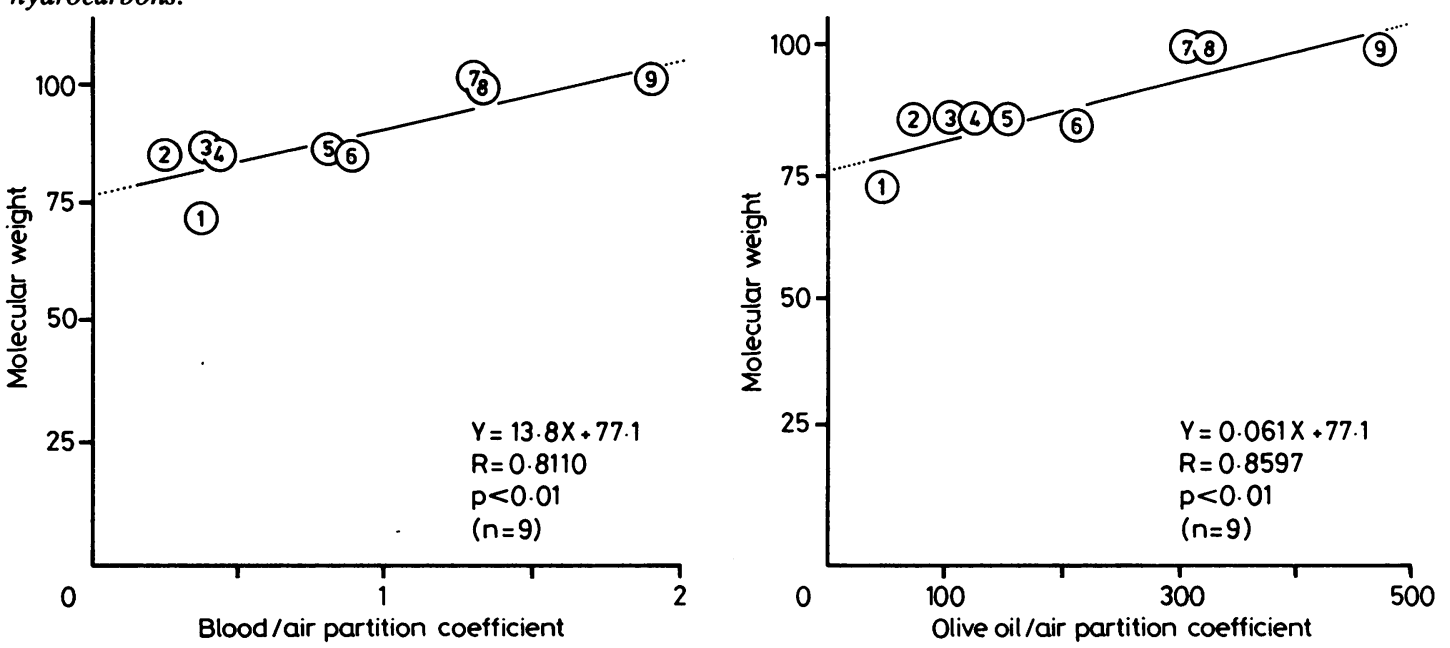

Fig 10 Correlation between blood/air and olive oil/air partition coefficients and molecular weights of solvents studied. 


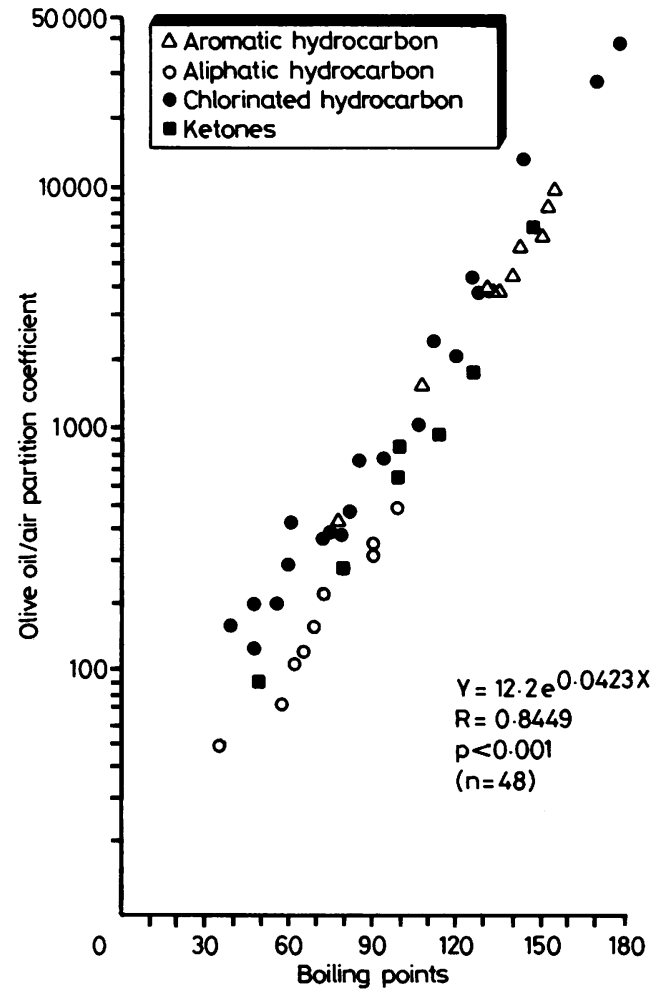

Fig 11 Correlation between olive oil/air partition coefficients and boiling points of different industrial solvents (aliphatic hydrocarbons: our data; ketones, aromatic and chlorinated hydrocarbons: data of Sato and Nakajima). ${ }^{4}$

was found between blood solubility $(Y)$ of the aromatic, aliphatic, and chlorinated hydrocarbons and their boiling points $(X)(Y=0.2264 \times$ ê 0.03 , $r=0.59 ; n=39 ; p<0.001)$.
This work was in part supported by the Italian National Research Council (CNR): finalised project on preventive and rehabilative medicine, subproject SP5, “Toxicological Risk," grant No 820213256.

Requests for reprints to: Dr Luigi Perbellini, Istituto di Medicina del Lavoro, Policlinico Borgo Roma, 37134-Verona, Italy.

\section{References}

' Eger EI. Anesthetic uptake and action. Baltimore: Williams and Wilkins, 1974.

2 Stewart A, Alliot PR, Cowles AL, Mapleson WW. Solubility coefficients for inhaled anaesthetics for water, oil and biological media. Br J Anesth 1973;45:282-93.

${ }^{3}$ Morgan A, Black A, Belcher DR. The excretion of breath of some aliphatic halogenated hydrocarbons following administration by inhalation. Ann Occup Hyg 1970;15:219-33.

4 Sato A, Nakajima T. Partition coefficients of some aromatic hydrocarbons and ketones in water, blood, and oil. $\mathrm{Br}$ J Ind Med 1979;36:231-4.

${ }^{5}$ Sato A, Nakajima T. A structure-activity relationship of some chlorinated hydrocarbons. Arch Environ Health 1979; 2:6975.

- Sherwood RJ. Ostwald solubility coefficients of some industrially important substances. Br J Ind Med 1976;33:106-7.

7 Van Rees $H$. The partition coefficients of styrene between blood and air and between oil and blood. Int Arch Arbeitsmed 1974;33:39-47.

B Brugnone F, Perbellini L, Grigolini L, Apostoli A. Solvent exposure in a shoe upper factory. I. n-Hexane and acetone concentration in alveolar and environmental air and in blood. Int Arch Occup Environ Health 1978;42:51-62.

- Perbellini L, Brugnone F, Grigolini L, Cunegatti P, Tacconi A. Alveolar air and blood dichloromethane concentration in shoe sole factory workers. Int Arch Occup Environ Health 1977; 40:241-7.

${ }^{10}$ Brugnone F, Perbellini L, Gaffuri E, Apostoli P. Biomonitoring of industrial solvent exposures in workers' alveolar air. Int Arch Occup Environ Health 1980;47:245-61. 